\title{
ANALYSIS OF INTEGRATED BUS TERMINAL SERVICES IN PULO GEBANG IN INCREASING CUSTOMER SATISFACTION
}

\author{
*Aswanti Setyawati ${ }^{1}$, Muhammad Nur Huda ${ }^{2}$, Suripno ${ }^{3}$, Hendy Tannady \\ 1,2,3 Institut Transportasi dan Logistik Trisakti, Jakarta, Indonesia \\ ${ }^{4}$ Kalbis Institut, Indonesia \\ *Coresponding author. \\ E-mail addresses: aswantimurgiyanto@gmail.com
}

\begin{abstract}
ARTICLE INFO ABSTRACT

Article history:

Received:

3 March 2021

Accepted:

15 April 2021

Available online:

4 Mei 2021

This study aims to analyze the service level of the Pulo Gebang Integrated bus terminal in increasing customer satisfaction. Based on the analysis and discussion, the results of the gap analysis between customer perceptions and expectations of 22 service attributes are all negative (-) with a range of -0.15 to $-1,49$. This indicates that the quality of service is still far from customer expectations, the attributes of interest after analyzing with the Importance Performance Analysis, the priority for improvement is obtained as well as in an effort to improve the quality of customer service at the Pulo Gebang Integrated bus terminal, after analyzing the approach with the Quality Function Deployment method, seven order of priority improvement.
\end{abstract}

Keyword: Service, Customer Satisfaction, Servqual, IPA and QFD

\section{INTRODUCTION}

DKI Jakarta Province has experienced many rapid developments in all fields due to being one of the Metropolitan Cities. These factors have resulted in the increasing flow of mobility to the DKI Jakarta Province. The large flow of mobility to the DKI Jakarta Province must of course be supported by good facilities and infrastructure so as not to cause problems that have an impact on the effectiveness of transportation.

The Pulo Gebang Integrated bus terminal with a land area of $12.6 \mathrm{H}$ and a building area of $5.4 \mathrm{H}$ is an Integrated Terminal which can be said to be similar to an airport, only simpler. So that it is one of the potentials to become a land gate in DKI Jakarta. This cannot be separated from the vital role of replacing two major terminals in Jakarta, namely Pulo Gadung and Rawamangun Terminals. It is hoped that the Pulo Gebang Integrated bus terminal will attract the interest of investors so that the wheels of the economy in DKI Jakarta in general and in the East Jakarta area in particular will be more stretched.

The DKI Jakarta Provincial Government has not yet maximally improved the Pulo Gebang Integrated bus terminal, both in terms of facilities and services. This is reflected in the presence of passengers and drivers who 
have not maximized using the Pulo Gebang Integrated bus terminal. It can be seen from the recapitulation of the number of bus arrivals and passengers for the 2016-2019 period:

Table 1 Recapitulation of Number of Bus Arrivals and Passengers at the Pulo Gebang Integrated bus terminal for the 2016-2019 period

\begin{tabular}{|c|c|c|c|c|c|c|c|c|}
\hline \multirow{3}{*}{ Month } & \multicolumn{6}{|c|}{ Year } & & \\
\hline & & & & & & & \multicolumn{2}{|c|}{2019} \\
\hline & Bus & Pax & Bus & Pax & Bus & Pax & Bus & Pax \\
\hline January & & & 5.461 & 88.420 & 6.757 & 101.148 & 3.290 & 44.646 \\
\hline February & & & 7.586 & 110.785 & 5.001 & 59.649 & 2.329 & 31.577 \\
\hline March & & & 8.531 & 121.722 & 5.456 & 64.202 & 2.294 & 36.466 \\
\hline April & & & 7.980 & 111.931 & 5.324 & 65.877 & 3.257 & 1.322 \\
\hline May & & & 7.466 & 103.866 & 4.125 & 58.509 & 2.794 & 32.900 \\
\hline Juni & & & 5.542 & 96.729 & 4.752 & 76.589 & 6.007 & 77.257 \\
\hline Juli & 2.646 & 56.187 & 10.509 & 211.640 & 5.409 & 82.267 & 4.148 & 68.292 \\
\hline Agustus & 3.789 & 52.708 & 6.479 & 80.506 & 4.165 & 44.410 & 3.909 & 56.554 \\
\hline September & 4.307 & 60.112 & 7.213 & 110.618 & 3.820 & 47.841 & 3.567 & 50.968 \\
\hline Oktober & 3.221 & 49.198 & 5.926 & 77.293 & 3.557 & 44.074 & 3.677 & 48.925 \\
\hline Nopember & 3.033 & 42.557 & 5.259 & 66.321 & 3.090 & 38.106 & 3.923 & 50.192 \\
\hline Desember & 3.756 & 56.087 & 7.466 & 103.866 & 3.370 & 47.276 & 4.903 & 62.129 \\
\hline Jumlah & 20.752 & 316.849 & 85.418 & 1.283 .697 & 54.826 & 729.948 & 44.098 & 561.228 \\
\hline
\end{tabular}

Source: Pulo Gebang Integrated Terminal Management Unit (2020

Based on the table above shows the increase and decrease of buses and passengers during the period 20162019, where passengers from 2018 amounted to 729,948 passengers to 561,228 passengers in 2019. In addition, according to the Jakarta City Transportation Council (DTKJ), there are many shadow terminals around Pulo Gebang. arises because the position of the terminal is considered not strategic. Pulo Gebang Terminal governance must be improved, because until now, the largest terminal in Jakarta, is still not optimal. If this is not immediately addressed, it is not impossible that the Pulo Gebang Integrated bus Terminal will be abandoned by Service Users.

Seeing the above conditions, it needs to be done in an effort to revive the Pulo Gebang Integrated bus Terminal, which is empty of passengers. Supranto (2016) states that, one way to measure people's attitudes towards the service quality of a service is to use a questionnaire regarding the level of satisfaction and the level of performance of these services. Furthermore, to answer the formulation of the problem regarding the extent to which the level of service user satisfaction with the performance of service servants, the authors use the Importance Performance Analysis (IPA) method or Analysis of the Level of Interest and Performance / customer satisfaction as well as Quality Function Deployment (QFD).

Based on the research gap conducted by previous research, Solehatin Ika Putri, Sumartini, Alifira Sofia (2017) with the results that the quality of the service of the West Cross West Local Economy Train is at a moderate level which indicates that the quality expected by customers has not been fulfilled. There are 21 indicators that can describe the dimensions of service quality with indicators related to the readiness of officers in directing the ladder of assistance from the platform to the train door which has the highest level of dissatisfaction. The recommended improvements that are a priority based on the results of the QFD analysis are to increase the supervision of the implementation of the SOP by the officers. In line with the research results of Dafazal Saffan, Bambang Syairudin, Fuad Achmadi (2018), where the results of the Cartesian diagram were processed with the House of Quality in QFD. The results of the SERVQUAL and QFD analysis show that five (5) main priorities are in the effort to increase customer satisfaction in Teluk Lamong Terminal, including: 1). evaluate the SOP of the behandle process; 2) adding personnel to TKBM officers at the location of the behandle; 3). provide special training for officers at behandle locations; 4). Trying to establish a communication network with Customs, if service users experience problems in NPE management; and 5). Upgrade forklift units if needed.

The objectives of this study are 1) To find out whether it meets the expectations of service users based on the gap value of the indicators of customer expectations or desires on the perceptions of the operational service quality of the Pulo Gebang Integrated bus terminal with the Service Quality (SERVQUAL) method; 2) To find 
out what service attributes are in quadrant one for program priority with the Importance Performance Analysis method: 3) To find out how the technical recommendations for redesigning the service operation of the Pulo Gebang Integrated bus terminal in increasing customer satisfaction with the QFD method

\section{METHODS}

Based on the theory put forward by Cresswel, the following stages of the research are as follows:

1) Planning

The activities carried out in this stage are as follows:

a) Preliminary survey

The first step that the writer took before selecting the topic was a survey first. The survey can be carried out through literature, practitioner resource persons, projects and consultations with supervisors.

b) Identification of problems

After the survey, problem identification will be carried out from all the problems found during the survey. From this identification process, the writer will find specific problem topics that will be studied more specifically.

c) Topic assignment

From the problem identification process above, the resulting output is a problem that the authors will examine more specifically.

d) Goal setting

After the topic is formulated, the next thing to do is determine the final objective / output of this research. Begin with what the end goal is in mind.

2) Implementation

At this stage the researcher acts as a research implementer as well as a human instrument to find data information and directly observe the condition of objects in the field, as follows:

a) Data collection

In this study, the following data were collected:

1. Data related to the number of buses at the Pulo Gebang Integrated bus terminal.

2. Data related to the number of passengers at the Pulo Gebang Integrated bus terminal

3. Primary data on existing conditions in the field.

b) Research implementation

The research was carried out by observing and surveying the existing service conditions at the Pulo

Gebang Integrated bus terminal, collect the necessary data and perform data processing and conduct interviews with sources related to the accumulation of data needed in research.

3) Data processing

The data processed in this study are data obtained from observations, surveys and interviews conducted by researchers as a basis for analysis and other supporting data.

4) Data Analysis

Data analysis was carried out after the researcher conducted interviews with sources and direct observation of objects in the field.

5) Comparison and analysis

From the data from interviews with sources and observations in the field, the level of satisfaction and customer needs will be obtained at the Pulo Gebang Integrated bus terminal.

6) Evaluation

All data related to the object of research in this case is the calculation of the measurement of the level of satisfaction and customer interests as well as customer needs analysis will be carried out to overcome these problems, so that things that cause dissatisfaction and neediness can be avoided.

As a case study, the data collected comes from various sources and the results of this study only apply to the cases investigated.

1) Descriptive Analysis 
According to Rangkuti (2012), descriptive analysis must be carried out carefully because if the average value shows relatively high results, this value must be compared with the standard deviation value.

2) Servqual Gap Analysis

Service quality (SERVQUAL) is used in collecting qualitative data obtained from questionnaire data. To look for gaps in the five quality dimensions using the Customer Satisfaction formula as follows:

$\mathrm{Q}=\mathrm{P}-\mathrm{E}$

Information:

$\mathrm{Q}=$ Quality of Customer Service

$\mathrm{E}=$ Customer Expectations for Service Quality

$\mathrm{P}=$ Service that is actually received

3) Importance Performance Analysis and Quadrant Analysis

Importance Performance Analysis (IPA) is an analysis of the level of importance and satisfaction. This study uses service attributes to define services at the Pulo Gebang Integrated bus terminal. This study uses a five-level scale or Likert scale $(1-5)$ to assess the level of importance and satisfaction of each service attribute.

The next stage, each service attribute will be included in the IPA quadrant according to the previously calculated average score of importance and level of implementation. The matrix is divided into four quadrants as shown in Figure 1 Quadrant A shows that the performance of a variable is lower than customer desires, so the company must improve its performance in order to be optimal. Quadrant B shows that the performance and customer desires for a variable are at a high and appropriate level, so that the company is sufficient to maintain the performance of these variables. Quadrant $\mathrm{C}$ shows that the performance and customer desires for a variable are at a low level, so the company does not need to make improvements. Finally, quadrant D shows that the company's performance is in a high level but the customer's desire for the performance of these variables is only low, so the company needs to reduce the results achieved, in order to streamline the company's resources.

4) Arrangement of Quality Houses (

The most important part of QFD is the establishment of a house of quality containing information about customer needs, level of customer importance, and customer perceptions and satisfaction.

5) Proposed Service Operational Design

From the results of the analysis and interpretation of the House of Quality which is produced through analysis using the Quality Function Deployment method, it will produce suggestions for improvements in improving the quality of service at the terminal Pulo Gebang Integrated Bus.

\section{FINDINGS AND DISCUSSION}




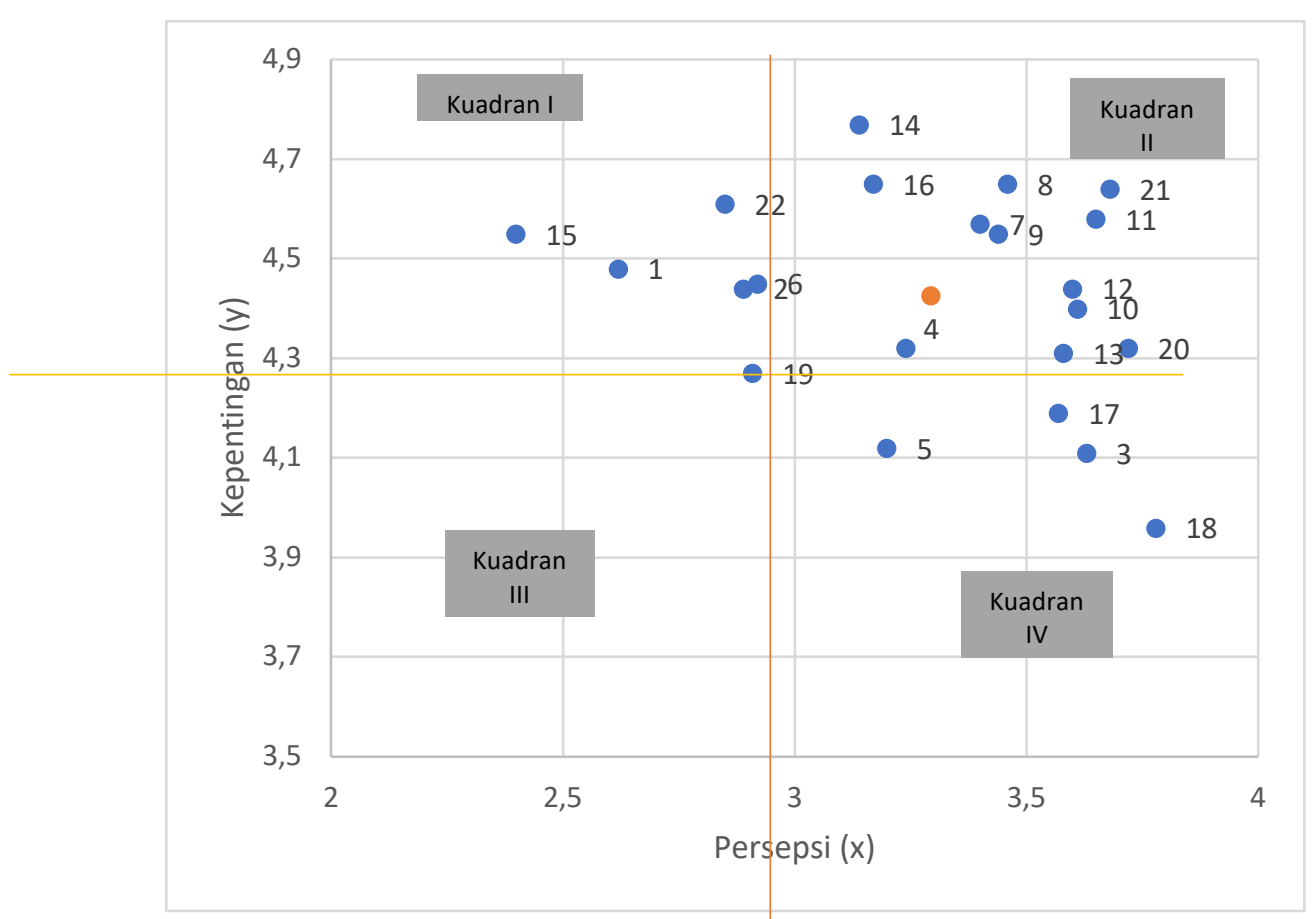

Figure 1. Natural Science Cartesian Diagram

Based on the analysis obtained using the IPA method, the following results were obtained:

a) Quadrant I (Top Priority)

In quadrant one, this is the quadrant that is the top priority or the most important for improvement. Because it has a high value of importance but the performance is still lacking. The attributes that exist in this unconscious are:

1) Punctuality of departure and arrival (1)

2) Access to the terminal location (2)

3) Quietness and comfort of the terminal (6)

4) Knowledge and skills of terminal officers in dealing with passenger complaints (14)

5) Guarantee of security and trust in service (15)

6) Convenience of existing facilities in the terminal (16)

7) Cleanliness and tidiness of buses and terminal staff (22)

b) Quadrant 2 (Maintain Achievement)

This second quadrant is a quadrant that can be said to be quite good. Where the importance is high and supported by high performance as well. Thus customers feel fast with the services provided. The following are attributes that are included in quadrant 2 :

1) Officers are fast and responsive in serving (7)

2) Responsive officers in helping customers (8)

3) Ease of obtaining information (9)

4) Honesty of officers in serving customers (11)

5) Polite and friendly ticket service (12)

6) Cleanliness in the terminal (21)

c) Quadrant 3 (Low Priority)

This third quadrant is a quadrant that is considered less important by customers, as well as their performance that is not given much attention. Some of the attributes that fall into this 3rd quadrant are:

1) The correct temperature of the air inside the terminal (4)

2) Suitability of the tariff with the services provided (5)

3) Give individual attention to passengers and people with disabilities (19)

d) Quadrant 4 (Excessive)

Attributes that enter this quadrant are said to be excessive due to excessive performance, while the 
importance for this attribute is low. The following attributes fall into quadrant 4:

1) Friendly staff in serving customers (3)

2) Easy access to bus tickets at the terminal (10)

3) Cleanliness in the terminal area (13)

4) Availability of ticketing and payment counters (17)

5) Tidiness of officers in uniform (18)

6) Has public facilities and good lighting (20).

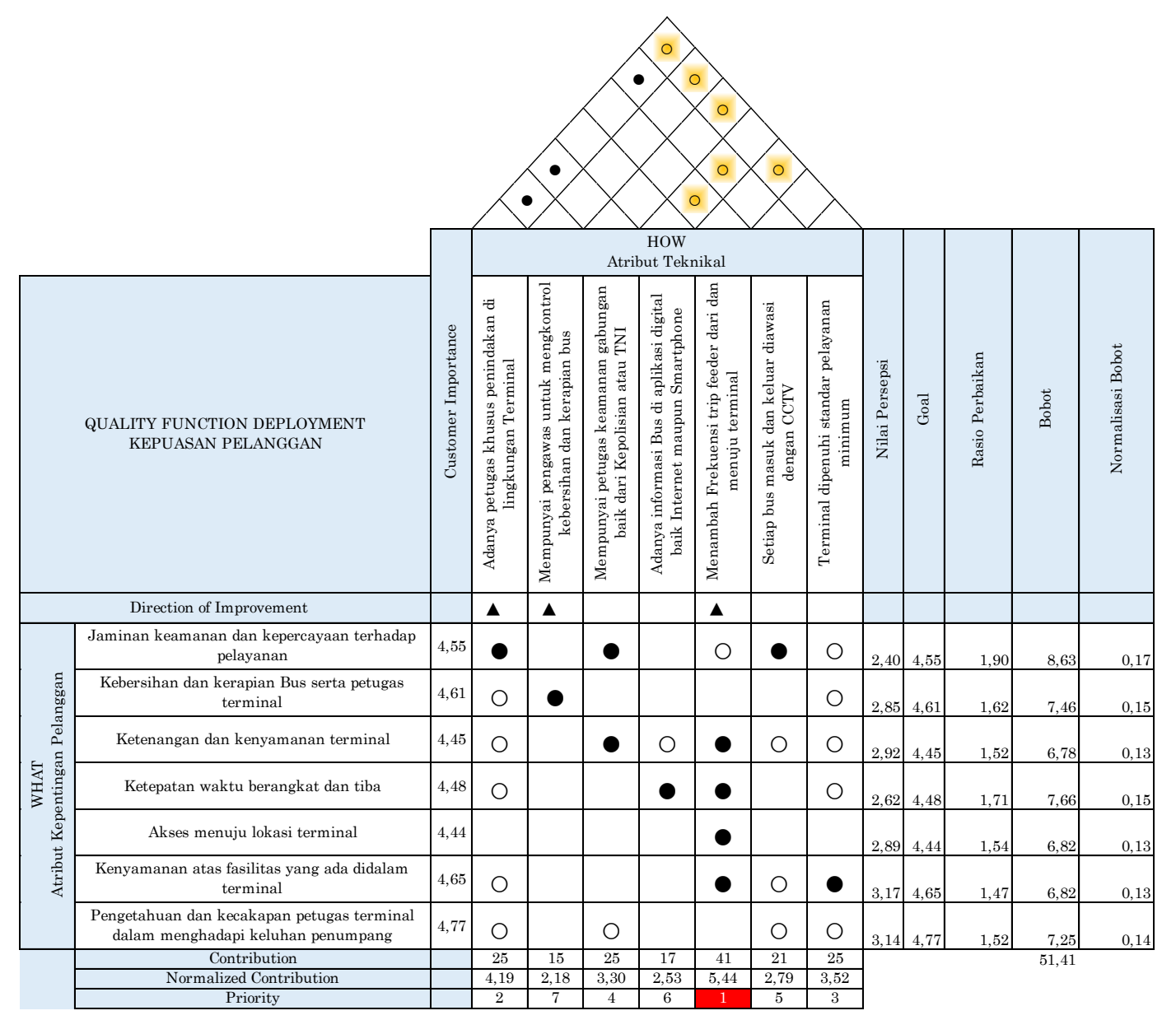

Figure 2. House Quality Matrix

The value of importance weight on the quality house matrix shows that increasing the frequency of the feeder trip to and from the bus terminal has the highest weight. Based on the analysis and discussion where the interests and expectations of customers for the Integrated Pulo Gebang Bus Terminal services from the implementation of Service Quality Integration and Importance Performance Analysis in the Quality Function Deployment are described as follows:

1) The results of the gap analysis between perceptions and customer expectations of 22 service attributes are all negative (-) with a range of -0.15 to -1.49 . This indicates that the quality of service is still far from customer expectations.

2) Attributes of importance and performance after analyzing the Importance Performance Analysis according to the Cartesian diagram, are as follows:

a) Quadrant I

1. Punctuality of departure and arrival (1)

2. Access to the terminal location (2)

3. Quietness and comfort of the terminal (6) 
4. Knowledge and skills of terminal officers in dealing with passenger complaints (14)

5. Guarantee of security and trust in service (15)

6. Convenience of existing facilities in the terminal (16)

7. Cleanliness and tidiness of buses and terminal staff (22)

b) Quadrant II

1. Officers are fast and responsive in serving (7)

2. Responsive officers in helping customers (8)

3. Ease of obtaining information (9)

4. Honesty of officers in serving customers (11)

5. Polite and friendly ticket service (12)

6. Cleanliness in the terminal (21)

c) Quadrant III

1. The correct temperature of the air inside the terminal (4)

2. Suitability of the tariff with the services provided (5)

3. Give individual attention to passengers and people with disabilities (19)

d) Quadrant IV

1. Friendly staff in serving customers (3)

2. Easy access to bus tickets at the terminal (10)

3. Cleanliness in the terminal area (13)

4. Availability of ticketing and payment counters (17)

5. Tidiness of officers in uniform (18)

6. Has public facilities and good lighting (20)

3) In an effort to improve the quality of customer service at the Pulo Gebang Integrated Bus Terminal, after analyzing the approach with the Quality Function Deployment method, the following order of priority improvements is obtained:

1. Increase the frequency of the feeder trip to and from the terminal

2. There is a special officer for enforcement in the Terminal environment

3. The terminal meets minimum service standards

4. Has a joint security officer from either the Police or the TNI

5. Every bus in and out is monitored by CCTV

6. The existence of Bus information in digital applications, both Internet and Smartphones

Has a supervisor to control the cleanliness and tidiness of the bus.

Based on the research gap conducted by previous research conducted by Solehatin Ika Putri, Sumartini, Alifira Sofia (2017) with the results of research on the quality of service of the West Cross West Local Economic Train, including at a moderate level which shows the quality expected by customers has not been met.Dewa Made Priyantha Wedagama, Putu Alit Suthanaya, dan Putu Ciria Angga Pramana (2020), analisis IPA hampir seluruh atribut pelayanan perlu ditingkatkan pelayanannya, untuk tingkat kepuasan pengguna jasa terhadap pelayanan diperoleh dari hasil analisis menggunakan metode CSI dimana saat ini tingkat kepuasaan pengguna jasa Bus Trans Sarbagita perhatian pramujasa dalam memberlakukan para penumpang secara profesional, ketepatan waktu keberangkatan Bus Trans Sarbagita dan keseusian antara jam layanan dengan waktu yang dibutuhkan oleh masyarakat.

Rini Alfatiyah, Apriyanto (2019), the results of data analysis using the Servqual method show that the results of data analysis show that there are 6 attributes that must be improved and in the QFD method, the results of data analysis obtained from the House Of Quality (HOQ) matrix indicate the application of culture. $4 \mathrm{~S}$ with the highest weight value. from 113.13, planning In customer satisfaction strategy, the priority that must be implemented by the company is to implement the 4S culture (Smile, Greetings, Greetings, Poles).

\section{CONCLUSION AND RECOMMENDATION}




\section{Conclusion}

Based on the analysis of the service level of the integrated bus terminal Pulo Gebang in increasing customer satisfaction with servqual and IPA in QFD as described in the previous chapters, the following conclusions can be drawn:

1) Based on the gap value analysis of the indicators of customer expectations or desires on the perception of the operational service quality of the Pulo Gebang Integrated bus terminal with the Service Quality method where the Pulo Gebang Integrated Bus Terminal has not been able to meet the expectations of service users in all service attributes, this is evidenced by all the value of the gap in all service attributes is negative (-). The attribute with question 15 (Security assurance and trust in service) has the highest gap value. The attribute with question no. 3 (Friendliness of officers in serving customers) has the lowest gap value.

2) 2. Service attributes in quadrant one for program priority with the Importance Performance Analysis method, namely timeliness of departure and arrival (1), access to terminal locations (2), tranquility and comfort of terminals (6), knowledge and skills of terminal officers in dealing with passenger complaints (14), guarantee of security and trust in service (15), comfort of existing facilities in the terminal (16) as well as cleanliness and tidiness of buses and terminal officers (22). All attributes are in quadrant I where their handling needs to be prioritized because these attributes are considered very important by service users, but their performance is still not satisfactory and is included in the onedimensional category, where for this need, customer satisfaction has a linear function with the performance of product attributes. High product attribute performance results in high customer satisfaction as well.

\section{Recommendations}

Based on the above conclusions, the authors provide the following suggestions:

1) To re-evaluate each service attribute, where customer expectations are still far from the performance or perception of services provided by the government. Whether it's conducting training for field employees who directly interact with customers, or by making improvements in the operation of the Pulo Gebang Integrated Bus Terminal so that it doesn't interfere with service.

2) Improvements that must be prioritized, namely the service attributes that are at the top priority, where it is the main interest for customers.

3) To improve service quality, researchers suggest service recommendations as follows:

a. Coordinate with related parties to increase the frequency of feeder trips to and from the terminal;

b. The need for additional security officers at the Pulo Gebang Integrated Bus Terminal;

c. Improve quality with training for Terminal officers to resolve passenger complaints in accordance with minimum service standards;

d. Coordinate with related parties by increasing the number of security officers;

e. The need for additional security officers and CCTV at every corner at the Pulo Gebang Integrated Bus Terminal;

f. Developing an application for purchasing bus travel tickets at the Pulo Gebang Integrated Bus Terminal to determine the arrival and departure times of buses;

g. Adding more personnel in the implementation of monitoring the cleaning and tidiness of buses in order to increase the comfort of service users.

\section{REFERENCES}

Astuti, H.J. (2012). Analisis Kepuasan Konsumen (Servqual Model dan Important performance Analysis Model). Jurnal Media Ekonomi. Vol 7(1): 1-20 
Atina, (2010). Analisis Kepuasan Pelanggan dan Kualitas Pelayanan dalam Memberikan Pelayanan Kesehatan di Rumah Sakit Menggunakan Metode Importance Performance Analysis dan Potential Gain In Customer Value's. Universitas Islam Indonesia, Yogyakarta

Creswell. J.W. (2013), Research Design (Pendekatan Kualitatif, Kuantitatif dan. Mixed) Edisi Revisi. Yogyakarta: Pustaka Pelajar

Dafazal Saffan, Bambang Syairudin, Fuad Achmadi. (2018). Analisis Kepuasan Pelayanan dan Loyalitas Pelanggan dengan Menggunakan Metode Servqual, IPA, dan QFD di Terminal Teluk Lamong. Business and Finance Journal, Volume 3, No. 1, March 2018

Dewa Made Priyantha Wedagama, Putu Alit Suthanaya, dan Putu Ciria Angga Pramana (2020). Analisis Kinerja Layanan Angkutan Umum Massal Bus Trans Sarbagita Berdasarkan Persepsi Kepuasan Penumpang Studi Kasus: Koridor I: Kota-Gwk Dan Koridor Ii: Batubulan-Nusa Dua). Jurnal Spektran Vol. 8, No. 1, Januari 2020, Hal. 11 - 18 ISSN: 2302-2590

Evans dkk, (2012) Perencanaan dan pengembangan produk dengan Quality Function Deployment (QFD). Jurnal Sains Manajemen \& Akuntansi. IV (1).

Firdha Fany Ardi, Iis Mariam dan Ni Made Widhi. (2016). Pengaruh Kualitas Pelayanan Pada Fasilitas Dan Petugas Commuter Line Ticket Vending Machine (C-VIM) Terhadap Kepuasan Konsumen PT KAI Commuter Jabodetabek Di Stasiun Pondok Cina. Epigram Vol. 13 No. 2 Oktober 2016

Ghozali, Imam (2011). SPSS 13.0 terapan : Riset Statistik dan Parametrik. Yogyakarta : CV. Andi Offset

Heizer, J \& Render, B. (2009). Manajamen Operasional, (ed.9), jilid.1, Jakarta : Salemba Empat.

Herni, (2015). . Analisis Kepuasan Konsumen pada BPRS Khasanah Umat (SERVQUAL Model dan Important Performance Analisis Model).

Kotler, Philip \& Amstrong, G. (2014). Prinsip-Prinsip Pemasaran, (ed.12), jilid.7, Jakarta : Erlangga

Kotler, Philip. (2013). Manajemen Pemasaran, Edisi Milinium, Jakarta : PT Prenhanllindo

Merriam, S.B. (2014). Case Study Research: A Qualitative Approach. San Francisco: Jossey. Bass.

Miles \& Huberman (2012) Analisis Data Kualitatif. Jakarta: Penerbit Universitas Indonesia

Moleong (2014). Metodologi Penelitian Kualitatif, Bandung: Remaja.

Nasution, Arman Hakim (2016). Perencanaan \& pengendalaian produksi, Yogyakarta : Graha Ilmu.

Nawawi, (2013). Penelitian Terapan, Gajah Mada University Press, Yogyakarta.

Noeng Muhajir (2013) . Metodologi Penelitian Kualitatif, cet I Yogyakarta,

Peraturan Menteri Dalam Negeri Nomor 6 tahun 2007 tentang Petunjuk Teknis Penyusunan Dan Penetapan Standar Pelayanan Minimal. Bab 1 Ayat 7

Peraturan Pemerintah Nomor 65 tahun 2005, tentang Pedoman Penyusunan dan Penerapan SPM.

Rangkuti, Freddy. (2012), Studi Kelayakan Bisnis \& Investasi. Jakarta : Gramedia Pustaka. Utama.

Rangkuti, Freddy. (2016). Teknik Mengukur dan Strategi Meningkatkan Kepuasan Pelanggan, Jakarta : PT. Gramedia Pustaka Utama

Rini Alfatiyah, Apriyanto (2019) Analisis Kualitas Pelayanan Parkir Dengan Metode Servqual, Ipa Dan Qfd Untuk Meningkatkan Kepuasan Pelanggan Di PT. Securindo Packatama Indonesia

Salim, A. A., (2013). Manajemen Transportasi. Jakarta. Penerbit : Rajagrafindo Persada

Sekaran, Uma. (2013). Research Methods for Business. Jakarta: Salemba Empat.

Solehatin Ika Putri, Sumartini, Alifira Sofia (2017) Metode Service Quality (Servqual) dan Quality Function Deployment (QFD) sebagai Usulan Perbaikan Kualitas Pelayanan di PT. Kereta Api Indonesia (Persero) (Survei pada Penumpang Kereta Ekonomi Lokal Lintas Barat Tahun 2017). Jurnal Ilmu Manajemen \& Bisnis - Vol 8 No 1 Maret 2017

Sugiyono, (2015). Metode Penelitian Bisnis, Bandung: Penerbit CV Alfabeta.

Sugiyono, (2017). Metode Penelitian Kuantitatif, Kualitatif dan R\&D. Bandung: Alfabeta.

Sukarto (2012) Pemilihan Model Transportasi di DKI Jakarta dengan Kebijakan Proses hirarki Analitik. Jurnal : Jurusan Teknik Sipil Fakultas Teknik Universitas Pelita Harapan

Supranto, J. (2016). Statistik Teori dan Aplikasi, (ed.7), Jilid.1, Jakarta : Erlangga..

Surjandari, Isti., (2010). Conjoint Analysis: Konsep dan Aplikasi.Penerbit Universitas Trisakti

Sutedi, A. (2012). Good Corporate Governance. Sinar Grafika. Jakarta

Sutopo (2016). Metodologi Penelitian Kualitatif. Surakarta: UNS

Tjiptono, Fandy dan Chandra, G. (2015). Pemasaran Strategi, Edisi 2, Yogyakarta : Andi

Tjiptono, Fandy. (2015). Manajemen Jasa. Edisi Pertama. Yogyakarta : Andi 
Trie Meisyah A, Herbasuki Nurcahyanto, Aufarul Marom (2016) Analisis Kepuasan Pelanggan Pada Stasiun Kereta Api Semarang Poncol (DAOP IV Semarang). Jurusan Administrasi Publik Fakultas Ilmu Sosial Dan Politik. Universitas Diponegoro

Utomo, H.S. (2012) Manajemen Transportasi, Malang:Pascasarjana Universitas Brawijaya

Wijaya, Toni. (2018). Manajemen Kualitas Jasa, Desain Servqual, QFD, dan Kano. Jakarta : PT Indeks. 